Magyar Honvédség Egészségügyi Központ Honvédkórház

Szív-, Ér-és Mellkassebészeti Osztály

\title{
Emlékezés Dr. Dékány Sándor ny. orvos ezredesre
}

\section{Dr. Pellek Sándor orvos alezredes PhD}

Kulcsszavak: honvédkórház, baleseti sebészet, missziók, vezetés, kutatás

\begin{abstract}
A cikk a szerző tanítómesterének, Dr. Dékány Sándor orvos ezredesnek (1942-2018), osztályvezető föorvosnak az életpályáját mutatja be. Életútján keresztül a katonaorvosi pálya jelentőségét, nehézségeit és egyben szépségeit is az olvasók elé tárja. Karrierjének állomásai tartalmazzák az előmenetel minden lépcsőjét. Az iskolateremtő képesség eredménye, a korszerü baleseti sebészeti tevékenység teljes spektrumának müvelése, és annak sikeres átadása az új generációknak példaértékü.
\end{abstract}

\section{Katonaorvosi pálya a Központi \\ Katonai Kórházban, missziós tevékenység Vietnamban és Jemenben}

Dr. Dékány Sándor 1942. szeptember 25-én született Diósgyőrben. 1966-ban végzett a Budapesti Orvostudományi Egyetem Általános Orvostudományi Karán „Summa cum laude” minősítéssel. 1966. szeptember 16. és 1967. március 15. között tartalékos egészségügyi tisztképző tanfolyamon vett részt, melynek végén tartalékos alhadnaggyá nevezték ki. 1973-ban, három hónapos tartalékos egészségügyi tiszti továbbképző tanfolyamot követően léptették elő tartalékos hadnaggyá.

Fiatal katonaorvosként korán felismerte, hogy a súlyos betegek ellátása csak többlépcsős folyamat során lehet igazán sikeres. A Központi Honvédkórház Bal- eseti Sebészeti osztályán a szubintenzív ellátás jelentőségét előrelátva, a részleg kialakítását kezdeményezte, majd munkahelyi vezetői támogatásával annak alapításában is oroszlánrészt vállalt. 1974. november 17. - 1975. május 21. között a Vietnami Nemzetközi Ellenőrző és Felügyelő Bizottság tagjaként Dél-Vietnamban szolgált („a mütétre szorulókat Dr. Dékány Sándor operálta ingyen. Néhány rászoruló betegének személyes kapcsolatai révén még térítésmentes kórházi elhelyezést is intézett. Ez óriási segítség volt, mert akkoriban Vietnamban, egy kórházban végzett mütétért félévi fizetésnek megfelelő összeget is elkértek.").

1975. szeptember 1-jén örnagyi rendfokozattal került hivatásos állományba, amellyel egyidejűleg kinevezték a budapesti Központi Katonai Kórház Baleseti Sebészeti osztály adjunktusává. 1977. június 12. és december 12. között a Jeme- 


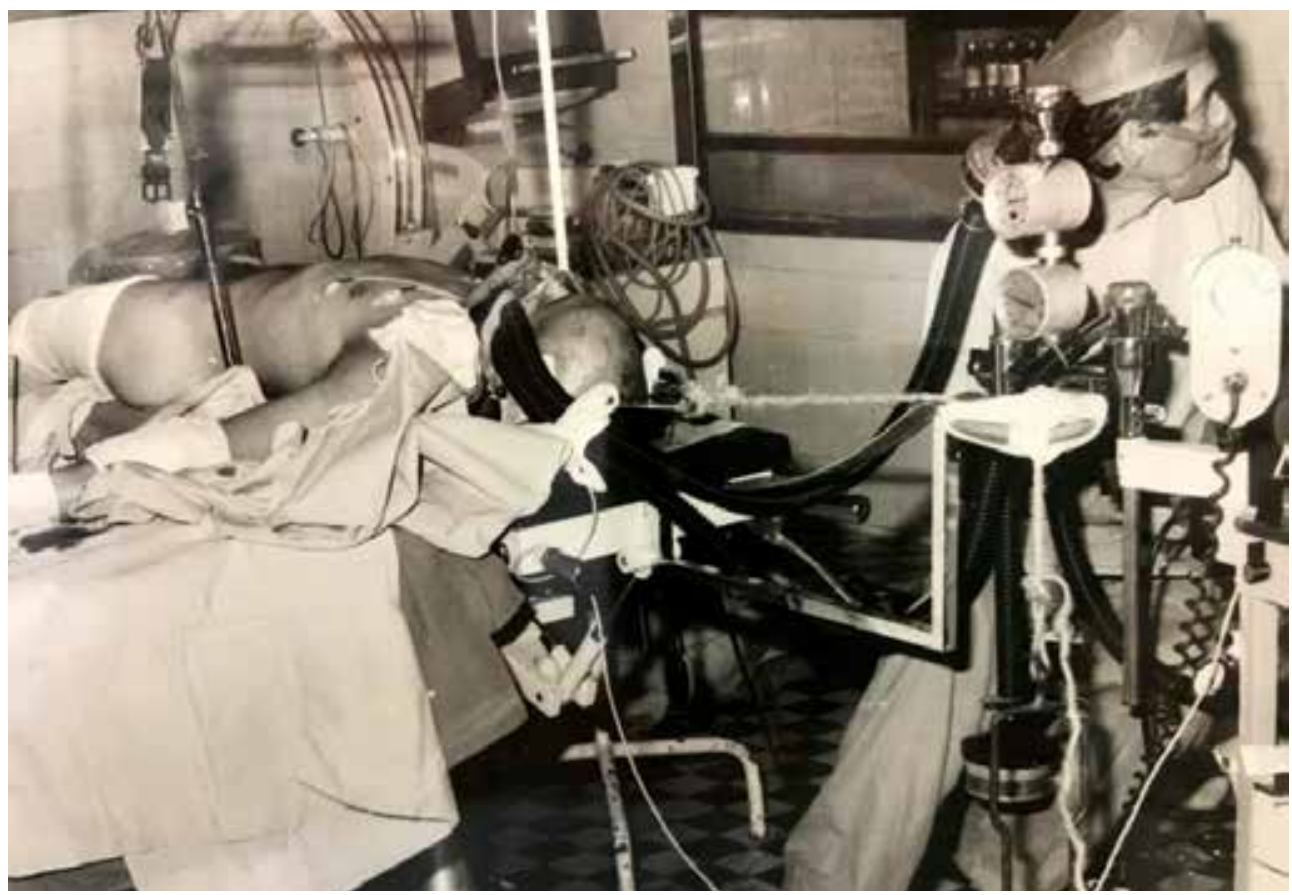

1. ábra. Dr. Dékány Sándor nyakcsigolya sérült beteget altat (Budapest, Központi Honvédkórház, 1974.)

ni Népi Demokratikus Köztársaságban katonaorvosi feladatokat látott el. 1981. április 1-jén a Budapesti Központi Katonai Kórház Rendelőintézetének baleseti sebész föorvosa lett, majd 1982. szeptember 1-jén alezredessé léptették elő.

\section{Vezető katonaorvosi tevékenysége Győrben}

\section{a MH 6. sz. Katonai Kórházban}

1982. december 1-jén a győri MN 6. sz. Katonai Kórház Baleseti Sebészeti osztály osztályvezető föorvosi beosztásába helyezték át. Felügyelte a katonai kórház építését, és megtervezte az új szakmai struktúra kialakítását. A haladó szellemiségü baleseti sebészet méretéhez képest jelentős fejlesztéseket kellett végrehajtani. A korszerü baleseti sebészet bővülő feladataihoz magas infrastrukturális és humánerőforrás fejlesztés vált szük- ségessé. Dr. Dékány Sándor vezetésével korszerü, európai szintű műtőblokk létesült, új mütéti eszközök beszerzésével. 1984. augusztus 1-jén a kórház fösebészévé nevezték ki.

Iskolateremtő vezető, a Magyar Baleseti Sebészet Szellemi Központja

$\mathrm{Az}$ általa megszervezett 120 ágyas Baleseti Sebészeti osztályon a maga köré gyüjtött fiatal, törekvő és tehetséges kollégáival, a szakmai fejlesztés kiterjesztésével elindította a kézsebészetet, majd a mikrosebészetet. Az új eszközök beszerzésével az ízületi csőtükrözés, az artroszkópia is teret hódított, amely a sportsebészet alapjait jelentette, biztonsági hálót nyújtva a város intenzív sportéletet folytató lakosainak.

$\mathrm{Az}$ általa kinevelt orvosok közül a barcelonai olimpia egészségügyi csapatába (1992) is biztosított szakembert. Vezetése alatt a budapesti Honvédkór- 
házhoz hasonlóan Győrben is életre hívta a Baleseti Sebészet Szubintenzív részlegét. Külföldi tanulmányútjain szerzett személyes tapasztalatait a saját osztályán kamatoztatta: elindulhatott a nagyízületi protézisek mütéti lehetősége a baleseti sebészeti-, valamint az ortopédiai betegeknél. Átlátta a szeptikus sebészet jelentőségét és preferálta az idegsebészet indítását, elvégezte az első, ágyéki gerinctörés stabilizálását fémlemezzel.

1991. január 4. és május 29. között az I. öbölháború magyar orvos missziójának tagjaként Szaúd-Arábiában szolgált. 1991. június 14-én ezredessé léptették elő. 1995. január 1-től 2006. június 1-jei nyugállományba helyezéséig a $\mathrm{MH}$ Győri Honvédkórház, illetve annak megszüntével a Györ-Sopron-Moson Megyei Kórház Baleseti Sebészeti osztály osztályvezető főorvosi, valamint a kórház fősebészi beosztását látta el.

Már 1992-ben kezdeményezte, hogy a korszerü súlyos sérült ellátáshoz az emberi testüregek sebészetét is fejleszteni kell, 1996-ban így jöhetett létre a győri kórházban a mellkas sebészet, amely sok beteg életét mentette meg.

Támogatta a gyógyszerkutatásokat. Irányításával egy nemzetközi vizsgálat igazolta, hogy a törések gyógyulását serkenteni lehet szintetikus növekedési hormon adásával. A 2003-ban indult - az ENSZ Biztonsági Tanácsa által támogatott - afganisztáni katonaorvosi missziókat az osztályán dolgozó fiatal orvosokat szaktudásával segítette. („Egy igazi baleseti sebész menjen háborúba, hogy ott segítsen és tanulja a szakmát" - Dr. Dékány Sándor orvos ezredes). Önzetlenül támogatta a hazai orvosi müszerfejlesztést.

Vietnámban 2000-ben és 2001-ben „vizitor Professor”-ként, a saigoni Orvostudományi Egyetemen számos mütét bemutatást tartott. A klasszikus trauma- tológiában is iskolateremtő volt. Tapasztalatait a Magyar Traumatológus Társaság vezetőségi tagjaként kamatoztathatta a hazai sérültellátás érdekében. Osztályvezetôi hozzáállása, baráti viselkedése kollégáinak és a betegeinek is példaként szolgált.

\section{A baleseti sebészet kézi könyve}

A Magyar Honvédség baleseti sebészete és katonaorvosi vezetése mindig elismert és rendkívül haladó szellemiségü személyekből állt. Fontosnak tartották a szakmai tapasztalatok kollektív megosztását és az új ismeretek közkinccsé tételét. Az első számú vezető felelőssége, hogy nemcsak a személyes tapasztalatait ossza meg, hanem egy szellemi erőteret létrehozva motiválja a legnagyobb szaktekintélyeket is, hogy azok a tudásukat egyesítve a legmagasabb szintü eredményt érhessék el. A Magyar Honvédség által jegyzett és szerkesztett baleseti sebészeti kézikönyvben (Operatív töréskezelés) Dr. Dékány Sándor több fejezetet jegyez. A technikai és a klinikai részekben is jelentőset alkotott. „Zárt, felfúrásos femur velöür szegezés" címü fejezetben felhívta a figyelmet a felfúrás során felszabaduló mediátor anyagok tüdőszövődményt (RDS - respiratorikus distress) okozó hatására. Tapasztalatai szerint lassú felfúrással és szegezéssel, megelőző légzés és gyógyszeres kezeléssel a szövődmények lehetősége jelentősen csökkenthető. A velöür felfúrás pontos méretezésével a vérvesztés számottevően mérsékelhető. A kíméletes erővel végzett felfúrás során a csontok vérellátása nem károsodik (mechanikai és hőhatás) és a szeptikus szövődmények elkerülhetők. A technikai szövődmények a szakszerü, kíméletes és pontos mütéti technikával megelözhetők. „A mütétet finoman, ésszel és érzés- 
sel, sohasem erőből végezzük."- hívta fel a kezdő baleseti sebészek figyelmét eme momentumra. A csípőtájéki törések ellátására kifejlesztett, „ Gamma szegezés” bemutatásával rámutatott, hogy használatával a szegezés speciális típusa forradalmasítja a proximális femurtörések ellátását (instabil femurtörések). A baleseti sebészeti implantátumok között felismerte a Marchetti-Vicenzi szegezés jelentőségét felkar és lábszártörések esetén. A rugalmas intramedulláris rögzítések elterjedésében szintén jelentős szerepet vállalt. A klinikai fejezetben a Kodifikáció (BNO, WHO), a betegségek nemzetközi osztályozási rendszer bevezetésének szükségességéről írt, amely a standardizált baleseti sebészeti szemlélet alapja.

\section{Innováció a fejlődés szolgálatában}

Dr. Dékány Sándor orvos ezredes felkarolta számos implantátum és operatív módszer nemzetközi elterjesztését. 2002-ben visszatért Vietnámba, Saigonba (Ho Chi Minh-város), ahol bemutató mütéteket végzett. A baleseti sebészet bonyolult eseteiben használt implantátumok fejlesztése folyamatosan foglalkoztatta. Tapasztalati alapján egy speciális alkarrögzítő rendszer fejlesztését és gyártását vezette. Ezeket az új rögzítő anyagokat a legbonyolultabb alkari törések fixálásában eredményesen alkalmazta. Az új implantátumot a kor szakmai trendjének megfelelően egyszerüsítette a következő céllal: „azok a legjobb, leglogikusabb rögzítö anyagok legyenek, melyeket mindenki azonnal használni tud."

\section{Ars poétikája a missziók után}

„Minden háború más jellegü. Az ember személyiségét jobban megérinti, ha szemtől szemben harcol az ellenséggel, s más, amikor „csak” ül a repülőgépen a katona és bombázza a célpontokat. Ilyenkor a halottakat és a sérülteket nem látja. Mindenesetre az idő nagyúr, lassan begyógyítja a sebeket. A vietnami háború az én személyiségemet is átalakította, pedig a helyzetem nem volt kifejezetten kellemetlen. Utána már se háborútól, se mástól nem féltem az életem során. Az Öböl-háború kitöréskor is csak arra gondoltam: menni kell segíteni! Elfoglaltam magam orvosi kérdésekkel, feladatokkal, s nem a szörnyüségekre gondoltam."

- Arra a kérdésre, hogy amikor arab sérülteket látott el, érezte-e az ön felé irányuló hálát, tiszteletet?

„Az arabok nem ilyenek! Úgy gondolják: Allah téged azért vezérelt oda, hogy meggyógyítsd őt, vagyis Allahnak hálásak, nem az orvosnak, aki előtt fekszenek a mütőasztalon.” - válaszolta $D r$. Dékány Sándor orvos ezredes.

\section{Katonai kitüntetések - a haza szolgálatában}

1975-ben a Vietnami Szolgálati Érdemérem, 1976-ban a Haza Szolgálatáért Érdemérem Ezüst fokozata, 1977-ben a Vietnami Felszabadítási Érdemrend és a Vietnami Fegyverbarátsági Érdemérem, 1980-ban a Haza Szolgálatáért Érdemérem Arany fokozata, 1981-ben a 10. év utáni Szolgálati Érdemérem, 1984-ben a Haza Szolgálatáért Érdemérem Arany fokozata ismételt adományozással, 1986ban a 15. év utáni Szolgálati Érdeméremmel ismerték el kiemelkedő katonai szolgálatát. A legnagyobb kitüntetésnek azonban kollégái megbecsülését és szeretetét tartotta, eme szemlélet végigkísérte az orvosi pályáján. Szakmai elismerésként a Magyar Traumatológus Társaság Lumniczer Sándor-emlékérmével tüntette ki. 


\section{A legmagasabb kitüntetés a kollégák elismerése - Aranyszike-díj}

2005-ben a Petz Aladár Megyei Oktató Kórháztól Nyári László Nívódíjban részesült. 2006-ban, nyugállományba vonulásakor kollégáitól „Aranyszike”díjat kapott. Nyugállományú osztályvezető föorvosként élete utolsó pillanatáig a mosonmagyaróvári kórház traumatológiai osztályának munkáját segítette, amely a fiatalok számára példaértékü kell, hogy legyen! Munkatársait nagyra tartotta és sohasem hagyta cserben őket, a legnehezebb esetekben sem!

\section{Irodalom}

[1] Harcban a halállal, Dél-Vietnam. Forrás: http://www.papp.gportal.hu/gindex.php?pg $=33486698 \&$ nid $=5753824$

[2] Pellek S., Dékány S.: Fél évtizedes mellkassebészeti tapasztalatok-fejlődési lehetőségek a PAMOK-ban. Orvos-Gyógyszerész Napok, Györ 2001. november 15-16.

[3] Pellek S., Dékány S.: Our experiences with Mesulid in Traumatology. Osztrák-Magyar Fiatal Traumatológusok Fóruma, Sopron, 2002. október 3-5.

[4] Pellek S., Dékány S.: Hungarian profile Study NN1606-1365 tibia fractures. Newsletter. Norditropin Simplex (Danish), 2002, 18.02.

[5] Hajba F.: A harctér etikája- NOL.hu, Népszabadság, 2014. 03.07. Forrás:http://nol.hu/ belfold/a-harcter-etikaja-1449011

[6] Pellek S., Dékány S.: Instabil medencesérülés komplex operatív ellátása. A 35 éves Magyar Traumatológus Társaság Jubileumi Vádorgyülése, Szeged, 2001. május 24-26.

[7] Pellek S.: A katonaorvosi képzés kérdései a NATO szövetségi rendszerében. Katonai Logisztika, 2016, 24. évf. Különszám
[8] Cziffer E. (szerk.): Operatív töréskezelés. Springer Hungária Kiadó Kft., 1997.

[9] Pellek S., Dékány S.: Velöürszegpolitika az ezredfordulón. A 35 éves Magyar Traumatológus Társaság Jubileumi Vádorgyűlése

[10] Jakócs P.: Allahnak hála, nem az orvosnak! Kisalföld c. napilap, 2007.12.18.

[11] Lumniczer Sándor Emlékérem díjazottak. Forrás:http://mtrauma.hu/lumniczer-sandor -emlékerem-dijazottak/

[12] Pellek S.: A sürgősségi betegellátás egyes kérdései a NATO multinacionális egészségügyi biztosítás rendszerében. Dr. Pellek Sándor PhD értekezése, Nemzeti Közszolgálati Egyetem, Hadtudományi Doktori Iskola. DOI azonosító: 10.17625/NKE.2013.010

\section{Lt.Col. S. Pellek MDMC, PhD}

\section{In memoriam Col. (ret.) S. Dékány MD}

The author, his master, Colonel Sándor Dékány MD., (1942-2018), head of department, presents his career. Through her life she reveals the significance, difficulties and beauty of the military medical course. This rich career includes all stages of career advancement in the clinical and missionary positions of clinical activity.The result of school-building ability, the cultivation of the full spectrum of modern accident activity and its successful transfer to the new generations are exemplary.

Key-words: military hospital, accident surgery, missions, management, research

Dr. Pellek Sándor o. alez., PhD 1134 Budapest, Róbert Károly krt. 44. 